\title{
Restoration of semi-natural grasslands, a success for phytophagous beetles (Curculionidae)
}

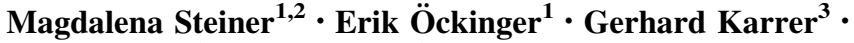 \\ Marie Winsa $^{1} \cdot$ Mats Jonsell $^{1}$ (D)
}

Received: 21 October 2015/Revised: 7 September 2016/Accepted: 24 September 2016/

Published online: 4 October 2016

(C) The Author(s) 2016. This article is published with open access at Springerlink.com

\begin{abstract}
Semi-natural pastures have rich plant and animal communities of high conservation value which depend on extensive management. As the area of such land decreases, abandoned semi-natural grasslands have been restored to re-establish biodiversity. Restoration schemes, which include thinning of woody plants and reintroduction of grazing, are mainly designed according to the responses of well-studied groups (such as vascular plants and birds). Weevils (Curculionidae) are a very diverse phytophagous beetle family. Here, we evaluated the restoration success of pastures for weevils (Curculionidae), by comparing their species diversity in abandoned, restored, and continuously grazed seminatural pastures on 24 sites in central Sweden. Weevils were sampled by sweep-netting.
\end{abstract}

Communicated by Dirk Sven Schmeller.

Electronic supplementary material The online version of this article (doi:10.1007/s10531-016-1217-4) contains supplementary material, which is available to authorized users.

Mats Jonsell

mats.jonsell@slu.se

Magdalena Steiner

magdalena.steiner@unifr.ch

Erik Öckinger

Erik.Ockinger@slu.se

Gerhard Karrer

gerhard.karrer@boku.ac.at

Marie Winsa

Marie.Winsa@slu.se

1 Department of Ecology, Swedish University of Agricultural Sciences, Box 7044, 75007 Uppsala, Sweden

2 Present Address: Department of Biology, Unit Ecology \& Evolution, University of Fribourg, Chemin du Musée 10, 1700 Fribourg, Switzerland

3 Department of Integrative Biology and Biodiversity Research, University of Natural Resources and Life Sciences Vienna, Gregor Mendel Street 33, 1180 Vienna, Austria 
We recorded 3019 weevil individuals belonging to 104 species. There was no statistically significant difference in species numbers between the pasture management treatments. However, weevil species composition of abandoned pastures differed from those in restored and continuously managed pastures, but there was no significant difference in community composition between restored and continuously grazed pastures. The abandoned sites tended to be dominated by polyphagous species, whereas the grazed sites contained more monophagous and oligophagous species. The number of weevil species was positively related to understory vegetation height and connectivity to other seminatural grasslands and negatively related to the cover of trees and shrubs in the pastures. We conclude that restoration of abandoned semi-natural pastures is a good approach to restore weevil communities. To maintain a species rich weevil community, pastures should be managed to be relatively open, but still have patches of tall field-layer vegetation. Restoration and conservation measures should primarily be targeted on regions and landscapes where a high proportion of semi-natural grassland still remains.

Keywords Agro-environment scheme · Biodiversity · Community composition · Grazing · Pasture · Weevils

\section{Introduction}

Increasing land use intensity on the one hand and the abandonment of traditional extensive management on the other hand are the two main drivers for the loss of semi-natural grasslands and the consequent loss of biodiversity (Strijker 2005; Silva et al. 2008). To counteract these negative effects, restoration and conservation measures are implemented by agro-environmental schemes on regional, national and European Union levels. These measures are expensive in terms of compensatory payments (European Commission 2012). Therefore it is necessary to evaluate not only their success regarding the recovery of seminatural grassland communities, but also extend these evaluations to less high profile taxa that are often overlooked (Kleijn and Sutherland 2003; Kleijn et al. 2011).

Temperate semi-natural grasslands (pastures and traditional hay meadows) are extremely species rich in many taxa (Dengler et al. 2014), and are among the habitats with the highest small-scale richness of plant species globally (Wilson et al. 2012). They are also important as source habitats for many species in the surrounding agricultural landscape (Öckinger and Smith 2007). Therefore, they have high values for conservation of biodiversity in agricultural landscapes. Due to the high plant and structural diversity in these grasslands, the invertebrate diversity is consequently high as well (Schaffers et al. 2008). Their biodiversity depends both on local habitat management and on the composition of the surrounding landscape (Öckinger and Smith 2006; Littlewood et al. 2012). Regular grazing is a disturbance regime necessary to maintain the grassland plant community (Hansson and Fogelfors 2000; Wilson et al. 2012). Grazed pastures typically also have a warm microclimate which is beneficial for many thermophilous insects (e.g. Thomas 1994). Pollinating insects typically benefit from more extensive grazing pressure, which leaves a higher abundance of pollen and nectar rewarding flowers (Söderström et al. 2001; Sjödin et al. 2008). Many semi-natural pastures contain scattered trees and shrubs, which can have a positive influence not only on the biodiversity of the species that depend directly on the trees and shrubs, but also on the biodiversity of the insects visiting flowering 
grassland species (Söderström et al. 2001; Caruso et al. 2015), probably by increasing the structural heterogeneity.

Semi-natural grasslands are not generally modified by intensive agricultural practices such as fertilizing, liming, herbicide use, or sowing of seed mixtures but instead depend on extensive management, i.e. mowing or grazing by livestock. The area of semi-natural grasslands in Europe has decreased rapidly during the past 50 years (Krauss et al. 2010) due to abandonment and the subsequent succession to woodland, or as a result of active transformation to arable fields or managed forests (Cousins 2009). In the short term, abandonment of pastures leads to taller vegetation and encroachment of shrubs and young trees. Early stages of succession show structural heterogeneity and favor thermophilic species on the south-facing microsites and shade tolerant species that prefer a cooler microclimate on the north-facing parts of vegetation structures (trees, shrubs, clonal patches of tall herbs and grasses) (Wallies DeVries 2006). With taller vegetation as well as the encroachment of trees and shrubs, the microclimate at the soil surface changes in patches to a more moist and cool environment (Gisi and Oertli 1981; Lenoir et al. 2013). Many grassland insects are thermophilous and may therefore be affected, even if their host plant is still present (Eilers et al. 2013). Some long-lived plant species can persist in suboptimal environmental conditions for a long time (Hylander and Ehrlén 2013), but on a longer term, grassland abandonment inevitably leads to a changed plant community composition (Peco et al. 2005). The semi-natural grassland specialists are replaced by a few species with high competitive ability or by forest-living species. In order to reduce biodiversity loss associated with abandonment of semi-natural grasslands, a national agro-environment scheme supported by the EU and targeted at restoration of abandoned meadows and pastures, has been implemented in Sweden (Jordbruksverket 2016).

The restoration actions for abandoned semi-natural grasslands include removal of encroaching trees and shrubs and the resumption of grazing by domestic livestock (Lindborg and Eriksson 2004). After the physical habitat conditions have been restored, the capacity to recolonize restored habitats depends both on species traits and on properties of the surrounding landscape, as well as their interactions (Suding 2011). For example, recolonization of restored grasslands can be considerably slower for species with low mobility than of more dispersive species, and is also slower for more specialized species than for generalists (Woodcock et al. 2012). Recolonization should also be positively related to connectivity, i.e. short distance to and/or large size of nearby patches (Hanski 1999). So far, the majority of studies in restoration ecology have focussed on the influence of local habitat characteristics and of different restoration techniques on restoration success, whereas the importance of landscape factors has received less attention (Brudvig 2011). There is a need to test how habitat fragmentation and other landscape characteristics restrict the capacity of species with contrasting traits to recolonize restored habitats.

So far studies on abandonment and restoration effects in semi-natural grasslands have been carried out for only a few taxa, such as vascular plants and a few insect taxa (Lindborg and Eriksson 2004; Pöyry et al. 2004; Öckinger et al. 2006a; Woodcock et al. 2010). As the correlation in species richness between grassland taxa is typically low (Vessby et al. 2002), it is important to include several taxa in such assessments, and especially to include poorly studied taxa. With approximately 60,000 described species worldwide, weevils are one of the most species rich families of the animal kingdom (Rheinheimer and Hassler 2012). In Sweden there are about 500 weevil species, i.e. phytophagous species of the superfamily Curculionoidea (=mainly Curculionidae and Brentidae; all bark beetles excluded; Lundberg and Gustafsson 1995), out of which about 100 species are nationally red-listed (ArtDatabanken 2015). Many weevils are specialized 
on certain plant genera or even single species (Rheinheimer and Hassler 2012). Many species have additional requirements such as warm microhabitats (Lennartsson 2010). Weevils are an under-studied group when it comes to biodiversity assessments of restoration success in Europe, even though they include grassland-associated and red-listed taxa (Woodcock et al. 2008, 2010).

Our aim in this study is to investigate how the weevil fauna responds to management and abandonment of semi-natural pastures, and how well weevil assemblages recover after grassland restoration consisting of clearing of young trees and shrubs and resumption of grazing by domestic livestock. This was done by comparing the weevil diversity and composition in continuously managed, abandoned and restored semi-natural pastures, and in restored pastures differing in the duration of time since restoration. Specifically, we considered:

1. Does the number of weevil species, number of weevil individuals or the composition of weevil communities differ between treatments (recently restored, old restored, abandoned and continuously grazed semi-natural pastures)?

2. Does the number of weevil species and individuals in restored semi-natural pastures increase with time since restoration and with connectivity to other semi-natural grasslands in the landscape?

3. Does the number of weevil species, number of weevil individuals or the composition of weevil communities, depend on management-related variables such as plant diversity, vegetation structure and tree and shrub cover and on connectivity, irrespective of restoration status?

4. Are weevil responses to pasture treatment dependent on host range (monophagy vs. polyphagy)?

\section{Materials and methods}

\section{The sites}

The study sites were 24 dry to mesic, grazed or abandoned (previously grazed) seminatural pastures, situated within the hemiboreal zone (Ahti et al. 1968) in eastern Sweden, in the counties of Uppsala, Stockholm and Västmanland (Fig. 1, long. $16^{\circ}-18^{\circ}$, lat. $59^{\circ}-$ $60^{\circ}$ ). The 24 pastures represented six replicates each of four treatments (Fig. 2): "Continuously grazed" were sites that had been grazed annually, or at least without any long interruption for more than 100 years; "Abandoned" were grazed until 22-51 years ago (Wärnsberg 2013) and were partially or completely overgrown with trees and shrubs; "Old restored" were previously abandoned but had been restored 10-17 years ago; and "Recently restored" were also previously abandoned but restored 3-7 years ago.

The selection process started with the 12 restored sites, which were pastures for which the landowners had received financial compensation for the restoration. This compensation is given for abandoned pastures that still contain some biodiversity associated with seminatural grasslands, and are estimated to fulfill the criteria for agro-environment schemes within 5 years. The selection was based on information obtained from the Swedish Board of Agriculture, County Boards, the Uppland foundation and several municipalities. Restored pastures were selected so that abiotic factors, such as soil and bedrock type, soil moisture and topography, were as similar as possible, and to achieve long gradients in the time since restoration and in connectivity to other semi-natural grasslands in the landscape. 

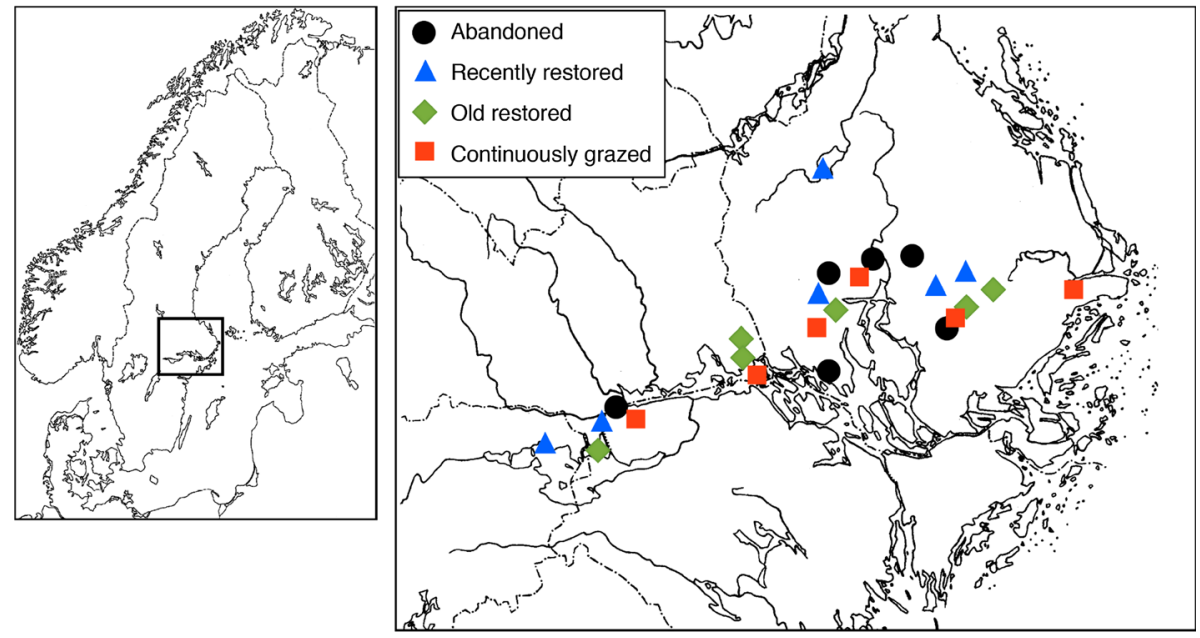

Fig. 1 The locations of the study sites, with their treatments indicated by different symbols
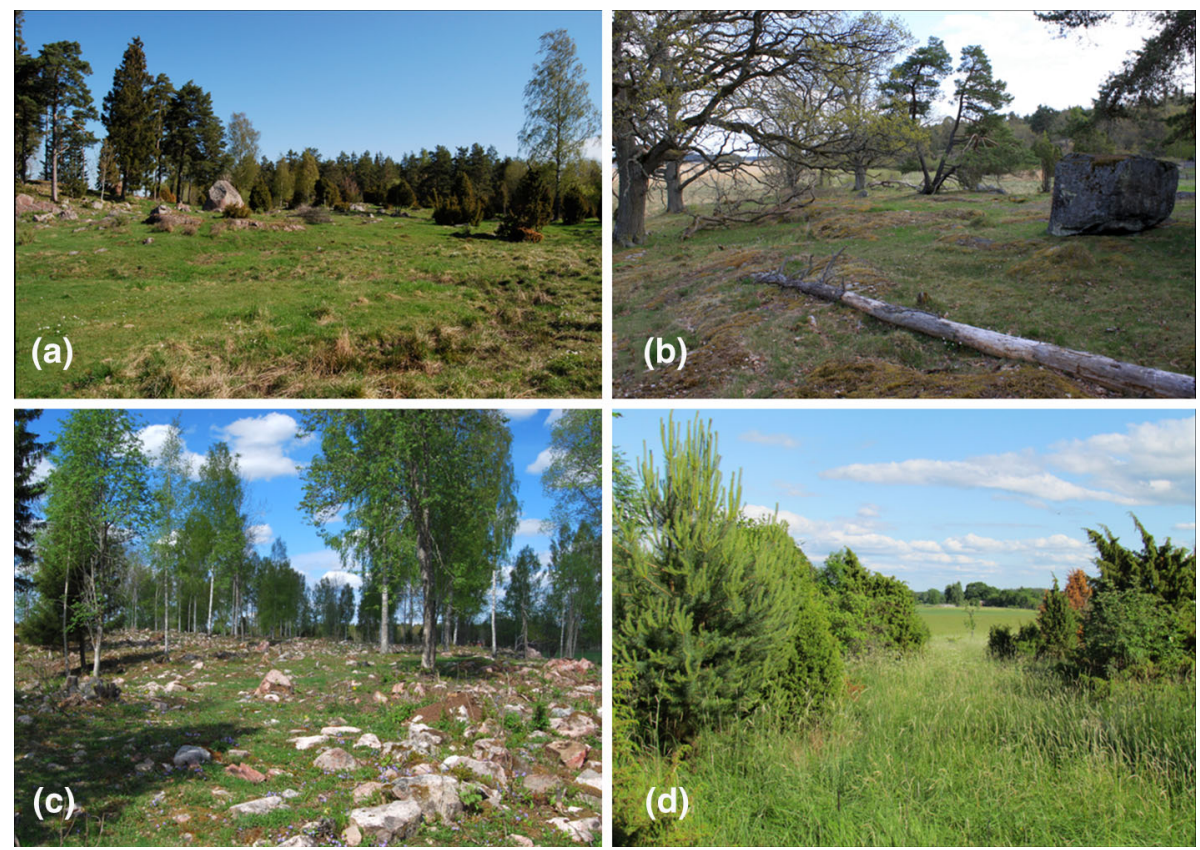

Fig. 2 The four treatments. a Continuously grazed site 'Läby'. b Old restored site 'Sjöängen Ängsö' (source Marie Winsa). c Recently restored 'Ahlezons Hage'. d Abandoned 'Grän, Rasbo'

To identify continuously grazed and abandoned pastures, we used a Swedish geographical database on semi-natural grasslands of high conservation value (HCV) (TUVA, (www. jordbruksverket.se/tuva), provided by the Swedish Board of Agriculture. This database was produced from a survey to identify high-biodiversity grasslands across Sweden, conducted during 2002-2004. These pastures were selected to match the restored pastures in soil type, 
soil moisture, topography and connectivity (see Online Appendix A), and hence represent the conditions before restoration (abandoned pastures) and the target stage (continuously grazed pastures). Pasture areas ranged from 0.79 to 7.6 ha.

\section{Sampling}

Each pasture was visited twice, the first time between the 14th and the 24th of May, and the second time between the 10th and the 19th of June 2013. All visits were on days with sunny, warm weather. The weevil fauna was sampled by sweep-netting. Four sampling plots were chosen at each site. Since the structural heterogeneity within pastures was considerable, a prior survey of the terrain was conducted to define areas with a species rich, homogenous herbal vegetation layer on mesic ground. Plots were large enough to permit 5 min of sweep-netting without resampling at any point (minimum about $200 \mathrm{~m}^{2}$ ). The sweep-netting was standardized to $5 \mathrm{~min}$, resulting in approximately 150 double sweeps with the net. To avoid variation due to ground moisture, sweep-netting was performed with a minimum distance of $1 \mathrm{~m}$ from structural features such as rocks with a diameter $>40 \mathrm{~cm}$, and from exceptionally dry or moist areas. Also, a minimum sampling distance of $10 \mathrm{~m}$ from the pasture edge was maintained. All sampling was performed by the same person. Weevils from the four plots were then pooled so all analyses were performed with pasture as the sampling unit.

\section{The environmental variables}

Six environmental variables were measured in each pasture: Area, Connectivity, Plant species richness, Vegetation height, Variability in vegetation height, and Tree and shrub cover (Table 1). Pasture area was calculated from aerial photographs. We calculated the connectivity of each pasture to all other semi-natural grasslands (meadows and pastures)

Table 1 Description of environmental variables

\begin{tabular}{|c|c|}
\hline Variable (unit) & Description \\
\hline Area $\left(\mathrm{m}^{2}\right)$ & Calculated area of the meadow using GIS \\
\hline Connectivity & $\begin{array}{l}\text { Describes the distance to multiple neighboring semi-natural pastures in the } \\
\text { landscape, by weighting the distance to each neighbor pasture according to its } \\
\text { area. See main text for a detailed formula }\end{array}$ \\
\hline Plant species richness & Number of plant species recorded by the plant diversity survey \\
\hline Vegetation height $(\mathrm{cm})$ & $\begin{array}{l}\text { Mean value from four sample plots at each site. The highest plants in the herbal } \\
\text { layers were measured (except single exceptional blades of grass) }\end{array}$ \\
\hline $\begin{array}{l}\text { Vegetation height } \\
\text { squared }\left(\mathrm{cm}^{2}\right)\end{array}$ & Squared measure of vegetation height \\
\hline $\begin{array}{l}\text { Variability in vegetation } \\
\text { height }\end{array}$ & $\begin{array}{l}\text { Measure of the variability in vegetation height within a grassland site, calculated } \\
\text { as the standard deviation of the four measurements of vegetation height in each } \\
\text { grassland }\end{array}$ \\
\hline $\begin{array}{l}\text { Tree and shrub cover } \\
(\%)\end{array}$ & Proportional cover of trees and shrubs of the site \\
\hline $\begin{array}{l}\text { Time since restoration } \\
\text { (years) }\end{array}$ & Only for restored sites: The number of years since restoration \\
\hline
\end{tabular}

For detailed information about the range of the variables see Online Appendix A 
with similar vegetation types, identified from the TUVA database. In the connectivity calculation, we considered semi-natural grasslands within a $5 \mathrm{~km}$ radius, using a modified version of the connectivity index (CI) described by Hanski (1999):

$$
\mathrm{CI}_{\mathrm{i}}=\Sigma \exp \left(-\alpha \mathrm{d}_{\mathrm{ij}}\right) \mathrm{A}_{\mathrm{j}}^{\beta}
$$

where $A_{j}$ is the area of the neighboring fragment $j$ (in hectares) and $d_{i j}$ is the distance (in $\mathrm{km}$, centre to centre) from the focal fragment $\mathrm{i}$ to the neighboring fragment $\mathrm{j} . \alpha$ is a speciesspecific parameter describing a species' dispersal ability and $\beta$ is a parameter that relates emigration probability to habitat area (Hanski 1999). Since we applied the connectivity index to an entire community with several taxa, we set the parameter $\alpha$ to 1 (corresponding to an average dispersal distance of $1 \mathrm{~km}$ ) and $\beta$ to 0.5 (c.f. Hanski 1999). The rank order of pasture connectivity is not sensitive to the value of these parameters (Moilanen and Nieminen 2002).

Plant species richness was measured by recording all plant species observed in 10 $1 \times 1 \mathrm{~m}$ plots in each pasture (Winsa et al. 2015). In the analyses we used the pooled plant species richness per pasture. Vegetation height was measured in each of the four beetlesampling areas as one measurement of the highest plants (except for single stems of grass protruding above the canopy). Since there was relatively little variation in vegetation height between pastures early in the season, we included only the vegetation height measurements at the second visit in the analyses. We used the average vegetation height per pasture, as well as the squared measure to test for non-linear effects. Additionally, we used the standard deviation of the four measurements of vegetation height in each pasture as a measure of the variability in vegetation height within a pasture. The Cover of trees and shrubs was estimated from aerial photographs from 2011 or 2012 as the percentage of the total pasture area covered by the tree or shrub canopy (Wärnsberg 2013). The variables were tested for collinearity with Pearson correlation coefficients. Only one statistically significant ( $\mathrm{p}=0.006 ; \mathrm{r}=0.545$ ) positive correlation was detected, between Area of the site and the Plant species richness. Since the correlation was relatively moderate we retained both variables in subsequent analyses.

\section{Species identification and classification}

The weevils were determined to species level except for the genus Sitona, since they proved to be very difficult to determine and they all have similar ecology. The main literature used for identification was Rheinheimer and Hassler (2012), supplemented by Freude et al. (1981) and Morris (2002). The nomenclature follows Löbl and Smetana (2003-2012). The species were also categorized into "host-range groups" as monophagous, oligophagous and polyphagous according to Rheinheimer and Hassler (2012). Species feeding on one single plant species were classified as monophagous, species feeding on several species within one plant genus were classified as oligophagous and species feeding on more than one plant genus were classified as polyphagous. The genus Sitona was not categorized. Red-listed species were defined according to ArtDatabanken (2015).

\section{Statistical analysis}

The beetle samples were pooled for each of the 24 pastures. The numbers of individuals were square-root transformed to obtain a normal distribution (Shapiro-Wilk's test: $\mathrm{W}=0.96, \mathrm{p}=0.47$ ). First, we tested for differences in mean number of weevil species 
and the mean total number of individuals between treatments in an ANOVA (using Proc GLM in SAS). Second, we tested if number of species and number of individuals in the restored pastures were related to the time since restoration, and if this effect was dependent on connectivity (i.e. if there was a time $\times$ connectivity interaction). Furthermore, we investigated whether other landscape and site characteristics (see environmental variables Table 1) had significant effects on the number of species or the number of individuals. We used a general linear model with Gaussian error distribution (multiple regression) using Proc GLM in SAS. Model simplification was by sequential deletion of least significant effects until a model was obtained containing only significant $(\mathrm{p}<0.05)$ variables.

To relate species composition to the environmental variables, we used unimodal ordination methods (DCA (Detrended correspondence analysis) and CCA (Canonical correspondence analysis)), as an initial DCA run showed the gradient on axis 1 to be 2.7 (Leps and Smilauer 2003). All species occurring in only one site were excluded from this analysis. The variable treatment was divided into three dummy variables (abandoned, restored old and continuously grazed), as categorical variables can only have the values 1 or 0 in the ordination analysis. To test which variables had an effect on species composition, we ran the CCA with Monte Carlo tests with 499 permutations. The automatic selection procedure was used, which includes the variables explaining most of the variation remaining after variables selected previously had been included in the model. The analysis was run with CANOCO 4.5 for Windows (ter Braak and Smilauer 1998).

The effect of different meadow management regimes on weevil species belonging to different host-range groups was analyzed with the average score for the species in each group along the first CCA axis. All species with more than one occurrence $(\mathrm{N}=67)$ were included in this analysis. Differences in CCA scores along axis 1 between the groups were tested using the Kruskal-Wallis test, a non-parametric test using the ranks of the scores. The test was run with Statview 5.0.1 for Mac.

\section{Results}

\section{Weevils}

Overall 3019 weevils of 104 species were collected from the 24 pastures (Online Appendix B). Of these species, $22 \%$ were represented by one individual only, $30 \%$ occurred only on one site and $42 \%$ of the species were represented by less than five individuals. The most abundant species were Protapion fulvipes, Protapion apricans, Protapion gracilipes, Sitona sp. and Omphalapion hookerorum, which were all represented by more than 100 individuals. In total these species constituted $54 \%$ of all recorded individuals. Two redlisted species were found: Protapion interjectum from three sites of different treatments (one abandoned, one continuously grazed and one old restored) and Ischnopterapion modestum in a recently restored site, all as singletons. The host-range group classification of the weevil species (excluding Sitona) categorized 19 species as monophagous, 55 as oligophagous and 26 as polyphagous (Online Appendix B).

\section{Species number and abundance}

There were no significant differences in beetle species number $\left(\mathrm{F}_{3,23}=0.17, \mathrm{p}=0.92\right)$ or number of individuals $\left(\mathrm{F}_{3,23}=0.16, \mathrm{p}=0.91\right)$ between the treatments (Table 2). The 
Table 2 Means $( \pm$ SE) and medians of the total numbers of weevil species per site and total abundance of weevils per site for each treatment

\begin{tabular}{lllllll}
\hline & & \multicolumn{2}{l}{ No. of species } & & \multicolumn{2}{l}{ No. of individuals } \\
Category & $\mathrm{N}$ & Mean & Median & & Mean & Median \\
\hline Continuously grazed & 6 & $24.0(3.70)$ & 23.0 & & $126.3(18.8)$ & 106.0 \\
Old restored & 6 & $25.7(2.60)$ & 25.5 & & $136.8(26.8)$ & 125.5 \\
Recently restored & 6 & $24.2(4.40)$ & 23.0 & & $125.0(38.3)$ & 107.0 \\
Abandoned & 6 & $22.2(3.07)$ & 21.5 & & $115.0(28.5)$ & 105.0 \\
\hline
\end{tabular}

For total numbers of species and individuals for each site see Online Appendix A

results were similar when the old restored and recently restored treatments were pooled (species number: $\mathrm{F}_{2,23}=0.22, \mathrm{p}=0.81$, individuals: $\mathrm{F}_{2,23}=0.11, \mathrm{p}=0.90$ ). Among the restored pastures, there was no effect of Time since restoration $\left(\mathrm{F}_{1,11}=1.26, \mathrm{p}=0.29\right)$ or Connectivity $\left(\mathrm{F}_{1,11}=0.90, \mathrm{p}=0.37\right)$, and no significant interaction of these variables $\left(\mathrm{F}_{1,11}=1.09, \mathrm{p}=0.30\right)$ on weevil species number. Similarly, neither Time since restoration $\left(\mathrm{F}_{1,11}=0.24, \mathrm{p}=0.81\right)$ nor Connectivity $\left(\mathrm{F}_{1,11}=0.62, \mathrm{p}=0.55\right)$ or their interaction $\left(\mathrm{F}_{1,11}=0.31, \mathrm{p}=0.77\right)$, influenced weevil abundance.

Regardless of the type of management, the number of weevil species in a pasture increased with Vegetation height (Fig. 3a; Table 3) and Connectivity to other semi-natural pastures in the landscape, but decreased with increasing Cover of trees and shrubs (Fig. 4; Table 3) and with increasing Variability in vegetation height (Table 3). There was also a trend of less species with increasing pasture Area. The total abundance of weevils was only related positively to vegetation height $\left(\mathrm{F}_{1,23}=9.79, \mathrm{p}=0.005, \mathrm{R}^{2}=30.8 \%\right.$, Fig. $\left.3 \mathrm{~b}\right)$.

\section{Species composition}

In the ordination space of the DCA, the continuously grazed sites are clustered at the right side (Fig. 5) and the abandoned sites at the left. The restored sites were arranged in between, with a tendency of the recently restored sites to be closer to abandoned and old restored being closer to continuously grazed sites. The total inertia was 2.88. A Monte Carlo test in a CCA was applied to test whether any of the variables could explain any significant variation in species composition. The variable Abandoned was the only significant one (Table 4), which means that Abandoned sites were significantly different from all other sites. No other model, with different combinations of variables, gave any significant explanation. The Eigenvalue of axis 1 in the CCA was 0.338 and that of axis 2 was 0.210 , and they explained 26.1 and $16.3 \%$ of the species-environment relation respectively.

\section{Effects of host-range groups}

In the CCA ordination space, axis 1 correlated with a management gradient. The polyphagous species were on average positioned closer to the abandoned sites, whereas monophagous and oligophagous were closer to the continuously grazed sites (Table 5). The difference between host-range groups was, however, not significant (Kruskal-Wallis test, $\mathrm{n}=67, \mathrm{H}=4.2, \mathrm{p}=0.12$ ). 

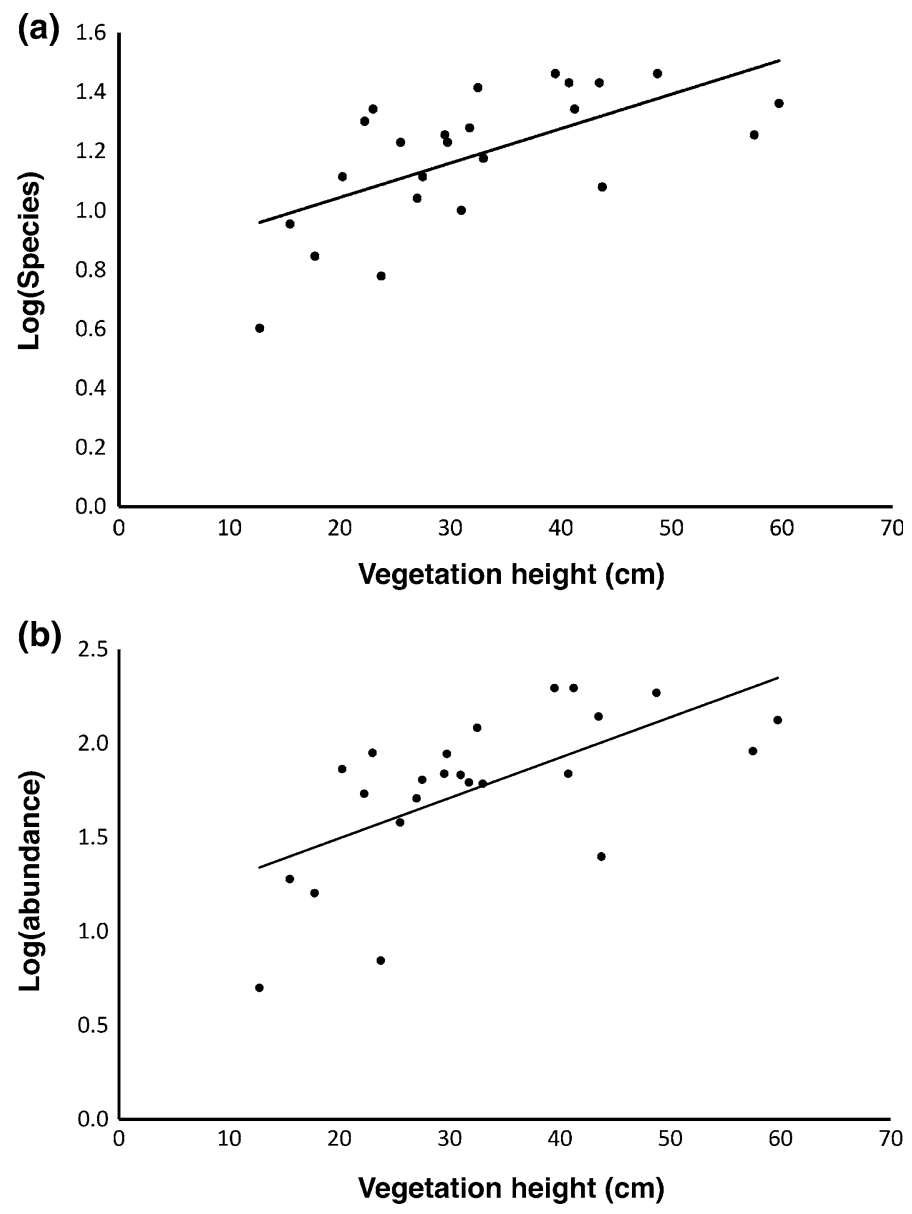

Fig. 3 Weevil species number (a) and abundance (b) is positively correlated with vegetation height

Table 3 Analysis of variance in a GLM with backward elimination for the number of weevil species

\begin{tabular}{lrrrrrrr}
\hline Source & DF & Seq SS & Adj SS & Adj MS & F & P & Coef \\
\hline Vegetation height & 1 & 615.8 & 618.26 & 618.26 & 30.50 & $<0.001$ & 0.62 \\
Variability in vegetation height & 1 & 249.0 & 112.30 & 112.30 & 5.67 & 0.028 & -0.65 \\
Tree and shrub cover & 1 & 130.6 & 171.90 & 171.90 & 8.71 & 0.009 & -11.70 \\
Connectivity & 1 & 77.2 & 122.70 & 122.70 & 6.21 & 0.023 & 0.54 \\
Log (area) & 1 & 63.9 & 63.90 & 63.90 & 3.24 & 0.089 & -6.83 \\
Error & 18 & 355.5 & 355.50 & 19.70 & & & \\
Total & 23 & 1136.5 & & & & & \\
$\mathrm{R}^{2}=76.2 \% \mathrm{R}^{2}(\mathrm{adj})=69.6 \%$ & & & & & & & \\
\hline
\end{tabular}




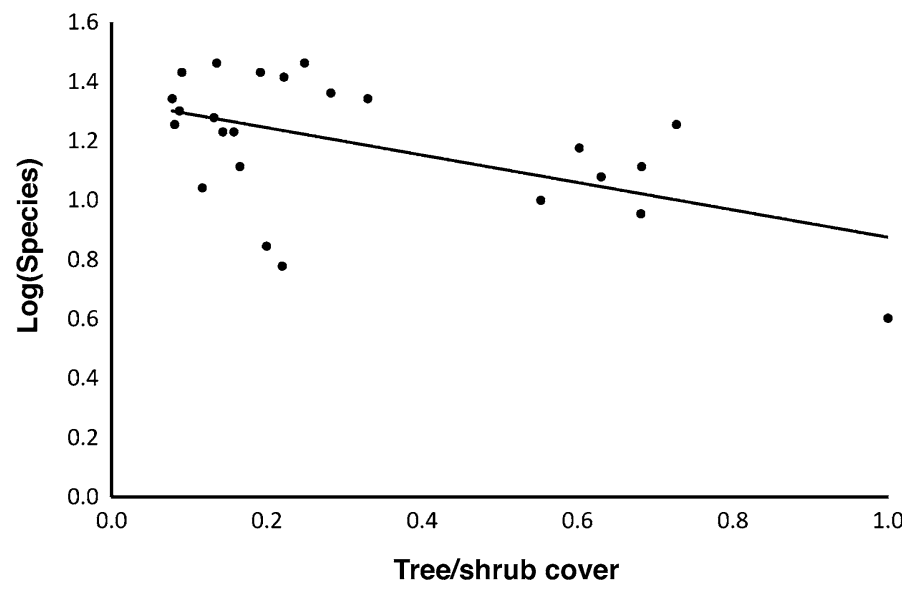

Fig. 4 Weevil species number decreases with increasing proportion cover of trees and shrubs

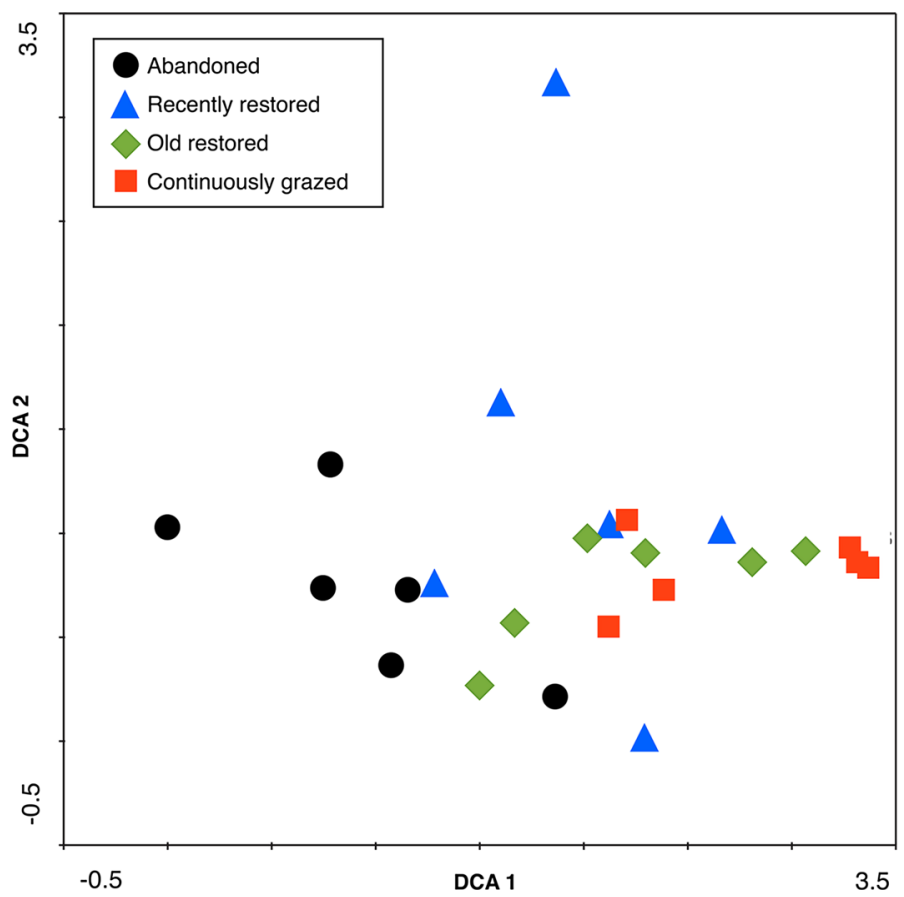

Fig. 5 DCA scatterplots of the study sites, which have their treatment indicated by different symbols. According to Monte Carlo test of the corresponding CCA, Abandoned sites are significantly different from the other treatments (Table 1$)$. Total inertia $=2.88$ 
Table 4 Environmental variables fitted in a stepwise forward selection in a CCA model, in automatically selected order

\begin{tabular}{|c|c|c|c|c|}
\hline \multicolumn{2}{|l|}{ Variable } & Lambda $\mathrm{A}^{\mathrm{a}}$ & $\mathrm{P}^{\mathrm{b}}$ & $\mathrm{F}$ \\
\hline \multicolumn{2}{|l|}{ Abandoned } & 0.27 & 0.002 & 2.24 \\
\hline \multicolumn{2}{|l|}{ Plant species richness } & 0.16 & 0.076 & 1.42 \\
\hline \multicolumn{2}{|l|}{ Continuously grazed } & 0.14 & 0.174 & 1.23 \\
\hline \multicolumn{2}{|l|}{ Connectivity } & 0.14 & 0.272 & 1.16 \\
\hline \multicolumn{2}{|l|}{ Variability in vegetation height } & 0.12 & 0.318 & 1.14 \\
\hline \multicolumn{2}{|l|}{ Old restored } & 0.12 & 0.382 & 1.05 \\
\hline \multicolumn{2}{|l|}{ Vegetation height squared } & 0.12 & 0.424 & 1.02 \\
\hline Area & & 0.09 & 0.734 & 0.79 \\
\hline Vegetation height & & 0.09 & 0.634 & 0.82 \\
\hline Tree and shrub cover & & 0.04 & 0.988 & 0.33 \\
\hline \multicolumn{5}{|c|}{$\begin{array}{l}\text { a Lambda A gives the amount of variation explained when the variable in question was included } \\
\text { b The significance of each variable was tested with Monte Carlo Permutation test (with } 499 \text { permutations) }\end{array}$} \\
\hline \multicolumn{5}{|c|}{$\begin{array}{l}\text { Table } 5 \text { Average score of different host-range groups along CCA axis } 1 \text {, representing the treatment-axis } \\
\text { (Fig. 6). The differences were not statistically significant (Kruskal-Wallis test: } n=67, H=4.2, p=0.12 \text { ) }\end{array}$} \\
\hline Host range group & $\mathrm{N}$ & Avera & & Mean rank \\
\hline Monophagous & 14 & 0.160 & & 31.4 \\
\hline Oligophagous & 39 & 0.018 & & 31.5 \\
\hline Polyphagous & 14 & 0.630 & & 43.5 \\
\hline
\end{tabular}

\section{Discussion}

Habitat restoration actions are conducted to mitigate the negative effects of land-use change on biodiversity. In contrast to our expectations, we found no significant differences in either weevil species numbers or weevil density between restored, abandoned and continuously grazed semi-natural pastures. A potential explanation for the lack of effect of abandonment on species numbers and abundance could be that there is an extinction debt Kuussaari et al. (2009), i.e. a high proportion of the grassland species still persists in abandoned pastures due to the slow extinction process, although the habitat has become unsuitable. Such an explanation is likely for long-lived plants, and the short-lived herbivores could exhibit a similar extinction debt if the extinction of their host plants is slow (c.f. Bommarco et al. 2014). However, analyses of weevil species composition indicated a shift in community composition. As the analysis across the pasture treatments revealed that the species composition of the abandoned sites differed significantly from that of restored and continuously grazed sites. This shows that some management-dependent species are replaced by other species during the succession in abandoned pastures. Analyses of the weevils' host-range groups indicated that more specialized species in continuously grazed pastures tend to be replaced by more generalistic ones in abandoned pastures. The community composition in restored pastures was intermediate between abandoned and continuously grazed pastures, but not significantly different from the latter. This shows that the restored, previously abandoned, pastures established a weevil species composition similar 


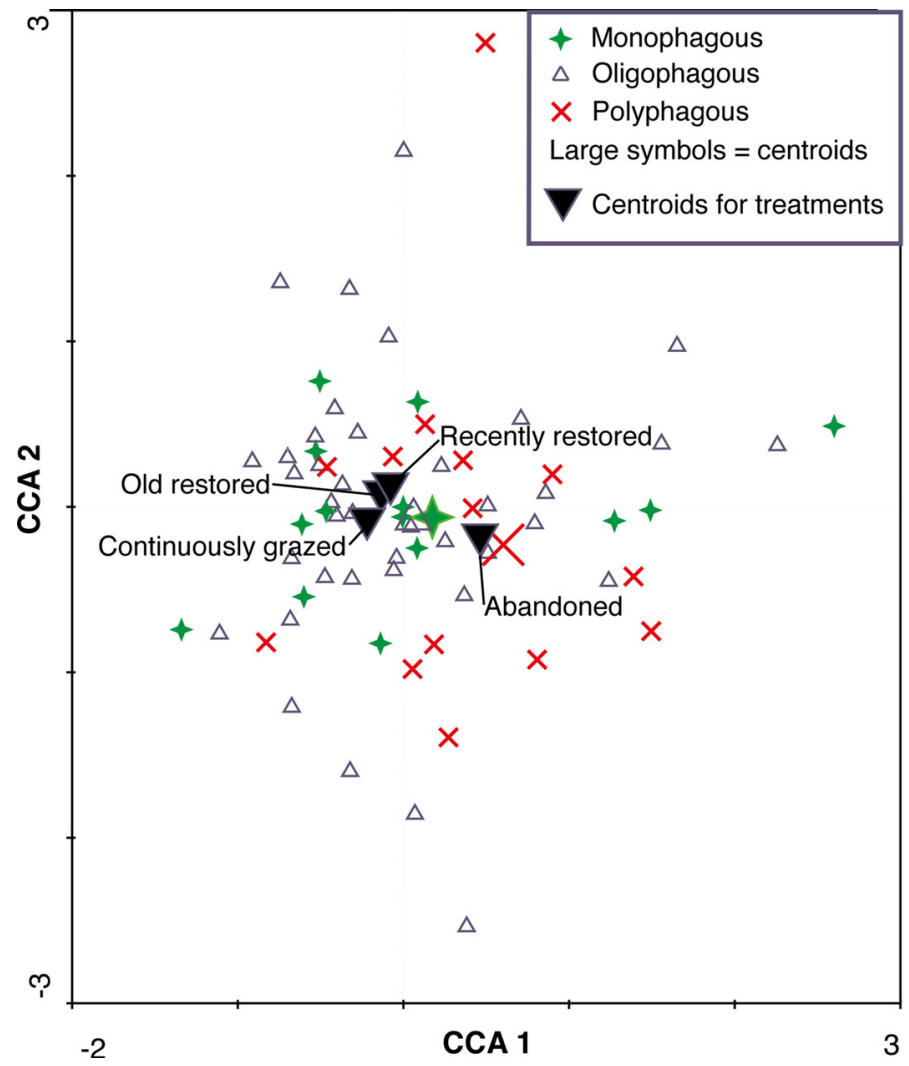

Fig. 6 Weevil species $(n=67)$ plotted in the CCA-ordination space with their host-range group indicated by different symbols, where large symbols are the centroids for the respective group. The treatments are depicted by their centroids of associated sites. Axis 1 (eigenvalue $=0.34$ ) and axis 2 (Eigenvalue $=0.21$ ) explain $68.5 \%$ of the variance of species-environment relation. Total inertia $=2.88$

to that of continuously grazed pastures, which suggests that restoration actions were successful in terms of community recovery.

Although the restorations were successful, with a community recovering towards that of the continuously managed sites, it is probably not possible to fully restore communities as they were when this type of grasslands dominated many landscapes. Some of the species that were present at these times are already regionally extinct. Management regimes are similar, but changed in small details, as well as e.g. climate and nitrogen deposition.

\section{Community recovery in time and space}

We found no increase in numbers of weevil species or weevil abundance with increasing time after restoration. This was contrary to our first expectations, but in accordance with the absence of effects of abandonment on species numbers and abundance. However, the species composition of restored sites tended to shift with increasing time since restoration, from being more similar to that in abandoned sites to becoming more similar to that in continuously grazed sites. Similar gradual shifts in species composition over time after 
restoration have also been observed for phytophagous beetles in natural grasslands in the UK (Woodcock et al. 2008, 2010). Even if the species are present soon after restoration, the changes in species relative abundances, which also influence community composition, could be slower and depend on the recovery of the plant community (Woodcock et al. 2010). Indeed, both the number of plant species (Winsa et al. 2015) and the plant community composition (Winsa et al., submitted manuscript) changed with the time since restoration in our study sites, and our results indicate that weevil communities are able to respond to the evolving plant communities.

Fragments of semi-natural grassland are typically small and isolated, and embedded in a matrix of arable land or production forest (Öckinger et al. 2012). For species specialized on grassland habitats, an analogy with oceanic islands, where species numbers depend on the balance between local extinction and re-colonization events, might be valid (MacArthur and Wilson 1967). As predicted, we observed more weevil species with higher connectivity, but surprisingly no positive effect of pasture area. Even though we found no effect of connectivity for restored pastures alone (possibly due to the lower sample size), this highlights the importance of considering the landscape context when selecting sites for restoration, or when designing agro-environmental schemes aimed at conservation and management of semi-natural grasslands (c.f. Öckinger and Smith 2006). Maintaining functional connectivity between grassland patches in the landscape probably allows for the persistence of weevil populations, even if local management is sub-optimal.

\section{Conservation value of the weevil fauna}

Abandoned pastures tended to have a higher abundance of polyphagous, i.e. generalist species than restored and continuously grazed pastures. This is similar to the results of Brown and Hyman (1986) who found more generalist weevil species in later successional stages from pastureland to woodland. A possible explanation could be that many of the polyphagous species feed on woody plants, which are more abundant in abandoned pastures, whereas most mono- and oligophagous species do not (Rheinheimer and Hassler 2012). Dietary specialized insect species are often more negatively affected by recent and ongoing landscape changes than generalist species (c.f. Hambäck et al. 2010; Öckinger et al. 2010), and have been suggested to be of higher conservational concern than generalists (Dennis et al. 2005). Hence, the higher abundance of specialist species in grazed pastures highlights the conservation value of these habitats also for weevils.

\section{Effects of pasture management}

Even though there was no difference in species number or abundance between restored, abandoned and continuously grazed pastures, we found strong effects of the structural components of the vegetation, which in turn are dependent on pasture management. The number of weevil species and individuals increased significantly with vegetation height. Similar results have been observed for plants, butterflies, bumblebees, hoverflies and flower-visiting beetles in Scandinavian semi-natural pastures (Öckinger et al. 2006a; Vessby et al. 2002; Sjödin et al. 2008). The positive relationship between vegetation height and species number remained even after abandonment. A potential mechanism is that more extensively grazed pastures also are more structurally diverse than intensively grazed pastures with a uniform, short turf (Tews et al. 2004). Grazing intensity can also influence plant species richness and community composition (Batary et al. 2010), which in turn could influence the phytophagous beetle richness via bottom-up effects. 
Increasing cover of trees and shrubs in pastures negatively influenced the number of weevil species. Previous studies have also found a negative effect of increasing tree and shrub cover on grassland plants and insects (Öckinger et al. 2006a, b). A potential mechanism is that extensive cover of trees and shrubs creates a more shaded environment and thereby a cooler microclimate (Suggitt et al. 2011), which can negatively affect many organisms associated with open grasslands (Öckinger et al. 2006b). Increasing cover of shrubs and trees might also affect the weevil fauna both directly, by decreasing the amount of habitat for thermophilic beetle species, and indirectly, through changes in the plant community composition.

\section{Conclusions}

Abandonment of previously grazed semi-natural pastures alters the community composition of weevils. Our results show, however, that even after a relatively long period of abandonment (up to five decades) it is possible to restore, to a large extent, weevil communities in such pastures by removing encroaching shrubs and young trees and re-introducing extensive domestic grazing. Such restoration actions should preferably be targeted on landscapes with relatively high densities of such grasslands. In the case of isolated grasslands, increasing connectivity by establishing or restoring functional networks of suitable grasslands, could be an efficient strategy.

Under current national agro-environment scheme (AES) regulations, semi-natural pastures must be grazed annually. Although grassland taxa show very different responses to grazing intensity (Kruess and Tscharntke 2002; Vessby et al. 2002), and the regular and relatively intensive grazing stipulated by the AES regulations are beneficial for some taxa, this is probably counteractive in terms of the conservation of weevil diversity, which benefited from tall vegetation. In order to enhance weevil diversity, we propose that AES regulations should be more flexible and allow some temporary patches with variation in vegetation height. This mismatch between AES regulations and patterns in weevil species numbers also highlights the need to consider the habitat requirements of less charismatic but highly diverse taxa, such as phytophagous beetles, in conservation and habitat restoration schemes.

Acknowledgments We thank Håkan Ljungberg for help with identifying critical specimens, and Ben Woodcock and one anonymous reviewer for constructive comments on the manuscript. Special thanks to the Entomological Society of Uppland, Sweden, for supporting this study with a scholarship to MS. EÖ and MW received funding from FORMAS.

Open Access This article is distributed under the terms of the Creative Commons Attribution 4.0 International License (http://creativecommons.org/licenses/by/4.0/), which permits unrestricted use, distribution, and reproduction in any medium, provided you give appropriate credit to the original author(s) and the source, provide a link to the Creative Commons license, and indicate if changes were made.

\section{References}

Ahti T, Hämet-Ahti L, Jalas J (1968) Vegetation zones and their sections in north-western Europe. Ann Bot Fenn 5:169-211

ArtDatabanken (2015) Rödlistade arter i Sverige 2015 (Red-listed species in Sweden 2015) ArtDatabanken SLU, Uppsala 
Batary P, Baldi A, Sarospataki M, Kohler F, Verhulst J, Knop E, Herzog F, Kleijn D (2010) Effect of conservation management on bees and insect-pollinated grassland plant communities in three European countries. Agric Ecosyst Environ 136:35-39

Bommarco R, Lindborg R, Marini L, Öckinger E (2014) Extinction debt for plants and flower-visiting insects in landscapes with contrasting land use history. Divers Distrib 20:591-599

Brown VK, Hyman PS (1986) Successional communities of plants and phytophagous Coleoptera. J Ecol 74:963-975

Brudvig LA (2011) The restoration of biodiversity: where has research been and where does it need to go. Am J Bot 98:549-558

Caruso A, Öckinger E, Winqvist C, Ahnström J (2015) Different patterns in species richness and community composition between trees, plants and epiphytic lichens in semi-natural pastures under agri-environment schemes. Biodivers Conserv 24:1729-1742

Cousins SAO (2009) Landscape history and soil properties affect grassland decline and plant species richness in rural landscapes. Biol Conserv 142:2752-2758

Dengler J, Janisova M, Török P, Wellstein C (2014) Biodiversity of Palaearctic grasslands: a synthesis. Agric Ecosyst Environ 182:1-14

Dennis RLH, Shreeve TG, Arnold HR, Roy DB (2005) Does diet breadth control herbivorous insect distribution size? Life history and resource outlets for specialist butterflies. J Insect Conserv 9:187-200

Eilers S, Pettersson LB, Öckinger E (2013) Micro-climate determines oviposition site selection and abundance in the butterfly Pyrgusarmoricanus at its northern range margin. Ecol Entomol 38:183-192

European Commission (2012) Agriculture and environment-agri-environment measures. http://ec.europa.eu/ agriculture/envir/measures/. Accessed 24 Oct 2013

Freude H, Harde KW, Lohse GA (1981) Die Käfer Mitteleuropas, Band 10: Bruchidae-Curculionidae. Goecke \& Evens Verlag, Krefeld

Gisi U, Oertli JJ (1981) Ökologische Entwicklung in Brachland verglichen mit Kulturwiesen IV. Veränderungen im Mikroklima. Oecol Plant 2:233-249

Hambäck P, Bergman K-O, Bommarco R, Krauss J, Kuussaari M, Pöyry J, Öckinger E (2010) Allometric density responses in butterflies: the response to small and large patches by small and large species. Ecography 33:1149-1156

Hanski I (1999) Metapopulation ecology. Oxford University Press, Oxford

Hansson M, Fogelfors H (2000) Management of a semi-natural grassland; results from a 15-year-old experiment in southern Sweden. J Veg Sci 11:31-38

Hylander K, Ehrlén J (2013) The mechanisms causing extinction debts. Trends Ecol Evol 28:341-346

Jordbruksverket (2016) https://www.jordbruksverket.se/amnesomraden/stod/jordbrukarstod/miljoersattnin gar/restaureringavbetesmarkerochslatterangar.4.6c64aa881525004b53bdbd74.html. Accessed 12 Feb 2016

Kleijn D, Sutherland WJ (2003) How effective are European agri-environmental schemes in conserving and promoting biodiversity? J Appl Ecol 40:947-969

Kleijn D, Rundlöf M, Scheper J, Smith HG, Tscharntke T (2011) Does conservation on farmland contribute to halting the biodiversity decline? Trends Ecol Evol 26:474-481

Krauss J, Bommarco R, Guardiola M, Heikkinen RK, Helm A, Kuussaari M, Lindborg R, Öckinger E, Pärtel M, Pino J, Pöyry J, Raatikainen KM, Sang A, Stefanescu C, Teder T, Zobel M, Steffan-Dewenter I (2010) Habitat fragmentation causes immediate and time-delayed biodiversity loss at different trophic levels. Ecol Lett 13:597-605

Kruess A, Tscharntke T (2002) Contrasting responses of plant and insect diversity to variation in grazing intensity. Biol Conserv 106:293-302

Kuussaari M, Bommarco R, Heikkinen RK, Helm A, Krauss J, Lindborg R, Öckinger E, Pärtel M, Pino J, Roda F, Stefanescu C, Teder T, Zobel M, Steffan-Dewenter I (2009) Extinction debt: a challenge for biodiversity conservation. Trends Ecol Evol 24:564-571

Lennartsson S (2010) Åtgärdsprogram för stäppspolvivel 2010-2014 (Pseudocleonus grammicus). Rapport 6335, Naturvårdsverket, Stockholm

Lenoir J, Graae BJ, Aarrestad PA, Alsos IG, Armbruster WS, Austrheim G, Bergendorff C, Birks HJ, Bråthen KA, Brunet J, Bruun HH, Dahlberg CJ, Decocq G, Diekmann M, Dynesius M, Ejrnaes R, Grytnes JA, Hylander K, Klanderud K, Luoto M, Milbau A, Moora M, Nygaard B, Odland A, Ravolainen VT, Reinhardt S, Sandvik SM, Schei FH, Speed JDM, Tveraabak LU, Vandvik V, Velle LG, Virtanen R, Zobel M, Svenning JC (2013) Local temperatures inferred from plant communities suggest strong spatial buffering of climate warming across Northern Europe. Glob Chang Biol 19:1470-1481

Leps J, Smilauer P (2003) Multivariate analysis of ecological data using CANOCO. Cambridge University Press, Cambridge 
Lindborg R, Eriksson O (2004) Effects of restoration on plant species richness and composition in Scandinavian semi-natural grasslands. Restor Ecol 12:318-326

Littlewood NA, Stewart AJA, Woodcock BA (2012) Science into practice: how can fundamental science contribute to better management of grasslands for invertebrates? Insect Conserv Biodivers 5:1-8

Löbl I, Smetana A (2003-2012) Catalogue of Palaearctic Coleoptera. Apollo Books, Stenstrup

Lundberg S, Gustafsson B (1995) Catalogus Coleopterorum Sueciae. Naturhistoriska riksmuseet, Stockholm

MacArthur RH, Wilson EO (1967) The theory of island biogeography. Princeton University Press, Princeton

Moilanen A, Nieminen M (2002) Simple connectivity measures in spatial ecology. Ecology 83:1131-1145

Morris MG (2002) True Weevils (Part I)—Coleoptera: Curculionidae. In: Hollis D (ed) Handbooks for the identification of British insects. Royal Entomological Society \& the Field Studies Council, London

Öckinger E, Smith HG (2006) Landscape composition and habitat area affect butterfly species richness. Oecologia 149:526-534

Öckinger E, Smith HG (2007) Semi-natural grasslands as population sources for pollinating insects in agricultural landscapes. J Appl Ecol 44:50-59

Öckinger E, Eriksson AK, Smith HG (2006a) Effects of grassland abandonment, restoration and management on butterflies and vascular plants. Biol Conserv 133:291-300

Öckinger E, Hammarstedt O, Nilsson SG, Smith HG (2006b) The relationship between local extinctions of grassland butterflies and increased soil nitrogen levels. Biol Conserv 128:564-573

Öckinger E, Schweiger O, Crist TO, Debinski DM, Krauss J, Kuussaari M, Petersen JD, Pöyry J, Settele J, Summerville KS, Bommarco R (2010) Life-history traits predict species responses to habitat area and isolation: a cross-continental synthesis. Ecol Lett 13:969-979

Öckinger E, Lindborg R, Sjödin NE, Bommarco R (2012) Landscape matrix modifies richness of plants and insects in grassland fragments. Ecography 35:259-267

Peco B, de Pablos I, Trabe J, Levassor C (2005) The effect of grazing abandonment on species composition and functional traits: the case of dehesa grasslands. Basic Appl Ecol 6:175-183

Pöyry J, Lindgren S, Salminen J, Kuussaari M (2004) Restoration of butterfly and moth communities in semi-natural grasslands by cattle grazing. Ecol Appl 14:1656-1670

Rheinheimer J, Hassler M (2012) Die Rüsselkäfer Baden-Württembergs. LUBW Landesanstalt für Umwelt Messungen und Naturschutz Baden-Württemberg, Karlsruhe

Schaffers AP, Raemakers IP, Sykora KV, terBraak CJ (2008) Arthropod assemblages are best predicted by plant species composition. Ecology 89:782-794

Silva JP, Toland J, Jones W, Eldridge J, Thorpe E, O'Hara E (2008) LIFE and Europés grasslands: restoring forgotten habitat. Luxembourg. doi:10.2779/23028

Sjödin NE, Bengtsson J, Ekbom B (2008) The influence of grazing intensity and landscape composition on the diversity and abundance of flower-visiting insects. J Appl Ecol 45:763-772

Söderström B, Svensson B, Vessby K, Glimskär A (2001) Plants, insects and birds in semi-natural pastures in relation to local habitat and landscape factors. Biodivers Conserv 10:1839-1863

Strijker D (2005) Marginal lands in Europe: causes of decline. Basic Appl Ecol 6:99-106

Suding KN (2011) Toward an era of restoration in ecology: successes, failures, and opportunities ahead. Annu Rev Ecol Evol Syst 42:465-487

Suggitt AJ, Gillingham PK, Hill JK, Huntley B, Kunin WE, Roy DB, Thomas CD (2011) Habitat microclimates drive fine-scale variation in extreme temperatures. Oikos 120:1-8

ter Braak CJF, Smilauer P (1998) Reference manual and user's guide to CANOCO for Windows: Software for canonical community ordination (version 4). Microcomputer Power, Ithaca

Tews J, Brose U, Grimm V, Tielbörger K, Vichmann MC, Schwager M, Jeltsch F (2004) Animal species diversity driven by habitat heterogeneity/diversity: the importance of keystone structures. J Biogeogr 31:79-92

Thomas JA (1994) Why small cold-bloded insects pose different conservation problems to birds in modern landscapes. Ibis 137(Supplement):112-119

Vessby K, Söderström B, Glimskär A, Svensson B (2002) Species-richness correlations of six different taxa in Swedish seminatural grasslands. Conserv Biol 16:430-439

Wallies DeVries M (2006) Larval habitat quality and its significance for the conservation of Melitaea cinxiai n northwestern Europe. In: Fartmann T, Hermann G (eds) Larval ökologie von Tagfaltern und Widderchen in Mitteleuropa. Abhandlungen aus dem Westfälischen Museum für Naturkunde, vol 68, pp 281-294

Wärnsberg J (2013) Artrikedom av kärlväxter i övergivna och restaurerade betesmarker: betydelsen av igenväxningsgrad och tid sedan igenväxning började. B.Sc. thesis 8. Department of Ecology, Swedish University of Agricultural Sciences, Uppsala

Wilson JB, Peet RK, Dengler J, Pärtel M (2012) Plant species richness: the world records. J Veg Sci 23:796-802 
Winsa M, Bommarco R, Lindborg R, Marini L, Öckinger E (2015) Recovery of plant diversity in restored semi-natural pastures depends on adjacent land use. Appl Veg Sci 18:413-422

Woodcock BA, Edwards AR, Lawson CS, Westbury DB, Brook AJ, Harris SJ, Brown VK, Mortimer SR (2008) Contrasting success in the restoration of plant and phytophagous beetle assemblages of speciesrich mesotrophic grasslands. Oecologia 154:773-783

Woodcock BA, VogiatzakisI N, Westbury DB, Lawson CS, Edwards AR, Brook AJ, Harris SJ, Lock KA, Maczey N, Masters G, Brown VK, Mortimer SR (2010) The role of management and landscape context in the restoration of grassland phytophagous beetles. J Appl Ecol 47:366-376

Woodcock BA, Bullock JM, Mortimer SR, Brereton T, Redhead JW, Thomas JA, Pywell RF (2012) Identifying time lags in the restoration of grassland butterfly communities: a multi-site assessment. Biol Conserv 155:50-58 